\title{
In-Field Corn Residue Management for Bioenergy Use: Potential Effects on Selected Soil Health Parameters
}

\author{
Mahdi M. Al-Kaisi1 ${ }^{*}$, Carlos Tenesaca² \\ ${ }^{1}$ Department of Agronomy, Iowa State University, Ames, USA \\ ${ }^{2}$ Department of Environmental, Ecology, and Organismal Biology, Ames, USA \\ Email: ^malkaisi@iastate.edu, charlie4@iastate.edu
}

How to cite this paper: Al-Kaisi, M.M. and Tenesaca, C. (2021) In-Field Corn Residue Management for Bioenergy Use: Potential Effects on Selected Soil Health Parameters. Open Journal of Soil Science, 11, 241-255.

https://doi.org/10.4236/ojss.2021.114013

Received: March 22, 2021

Accepted: April 22, 2021

Published: April 25, 2021

Copyright $\odot 2021$ by author(s) and Scientific Research Publishing Inc. This work is licensed under the Creative Commons Attribution International License (CC BY 4.0).

http://creativecommons.org/licenses/by/4.0/

\begin{abstract}
In the U.S. biofuel industry is using corn (Zea mays L.) residue mix (CRM) consisting of corncob and stover for cellulosic ethanol and biogas production. The field storage method left different depths of CRM on the field after its removal, where negative effects on plant growth were observed. The objective of this study is to evaluate the CRM effect on selected soil health indicators. The field study conducted with four different depths of CRM, two tillage systems (no-till (NT) and chisel plow (CP), and three nitrogen $(\mathrm{N})$ rates $(0,180$, and $\left.270 \mathrm{~kg} \cdot \mathrm{N} \cdot \mathrm{ha}^{-1}\right)$ in a randomized complete block design with split-split arrangements in three replications in a continuous corn system from 2010 to 2012 at the Agronomy Research Farm at Iowa State University. The findings of this study showed a negative effect on soil organic carbon (SOC) change across all treatments at $0-15 \mathrm{~cm}\left(-0.35\right.$ to $\left.-0.03 \mathrm{Mg} \cdot \mathrm{ha}^{-1} \cdot \mathrm{yr}^{-1}\right)$, while at 15 $30 \mathrm{~cm}$ there was an increase in SOC rate $\left(0.13\right.$ to $\left.0.40 \mathrm{Mg} \cdot \mathrm{ha}^{-1} \cdot \mathrm{yr}^{-1}\right)$ after 2-yr. In addition, soil aggregate-associated $\mathrm{C}$ of macro-aggregates decreased by $8 \%$, while micro-aggregates increased by $2 \%$. Soil microbial biomass carbon (MBC) across tillage and $\mathrm{N}$ rates for $2.5 \& 7.5 \mathrm{CRM}$ treatments increased by $14 \%$ in June to July 2011, while in 2012 increased by $9 \%$. However, at the 15 $\mathrm{cm}$ soil depth, soil bulk density $\left(\rho_{\mathrm{b}}\right)$, soil penetration resistance (SPR), and soil $\mathrm{pH}$ showed no significant differences among CRM treatments. The findings of this study showed that in-field CRM management can affect certain soil health parameters in the short term.
\end{abstract}

\section{Keywords}

Residue Management, Tillage, Soil Organic Carbon, Soil Health, Microbial Biomass Carbon 


\section{Introduction}

In the past two decades the transformation of energy from fossil fuel base to bioenergy sources encouraged the establishment of a new industry; which is dependent on corn (Zea mays L.) grain as the main feedstock material for biofuel production in the Midwest, U.S. [1]. Recently, corn residue has been considered by the bioenergy industry as a viable feedstock source for cellulosic ethanol production [2]. The use of corn grain and crop residue for ethanol production and biogas has the potential to reduce fossil fuel consumption and greenhouse gas emissions [2] [3]. However, methods of collection and storage of feedstock for cellulosic ethanol production in the Midwest, U.S., can present significant challenges to soil health and plant growth.

The storage method consists of piling corn stover and corncob residue mix (CRM) at the edge of the field after harvest, where it is stored over winter until it is collected and transported for processing the following spring. Field observations of corn planted in CRM storage areas after removal exhibited poor plant development and yield reduction the following season. In Iowa, where soils are inherently fine-textured with poorly drained conditions, storing and handling CRM can have significant effects on soil moisture, nitrogen $(\mathrm{N})$ availability, and tillage timing. These conditions present challenges for soil and crop residue management, which are essential to provide optimal seed conditions for germination, seedling development, and plant growth [4] [5].

In our initial field observations, CRM storage areas showed soil compaction due to heavy equipment traffic used to store and remove CRM; these soil compacted areas caused surface runoff, soil erosion, and subsequent decrease in plant aboveground biomass and grain production [2]. Careful management of CRM left after residue removal is essential to maintain healthy soil conditions to ensure healthy crops. Therefore, CRM on poorly drained soils, if not managed correctly, may cause autotoxic effects on seedlings, which slows plant growth and development [5] [6], and often leads to slow plant emergence and $\mathrm{N}$ mineralization [7] [8].

CRM on the soil surface can influence $\mathrm{N}$ availability early in the growing season, where cold soil temperatures slow SOC mineralization affecting plant $\mathrm{N}$ use and accumulation [5] [9]. Thus, CRM requires the integration of management practices that include tillage and $\mathrm{N}$ application to overcome initial $\mathrm{N}$ supply limitation. Adequate $\mathrm{N}$ fertilization can aid in soil $\mathrm{C}$ retention by increasing below and aboveground biomass production as a source for SOC input [10] [11]. However, the sustainability of CRM storage methods will depend heavily on the cropping system, $\mathrm{N}$ fertilization, climate, and soil type [12], for each region to minimize the potential negative impact on soil physical, chemical, and biological properties. The objectives of this study were to investigate the potential effects of CRM on the soil surface and its interaction with soil physical and biophysical properties. Also, to evaluate potential management practices such as tillage systems and $\mathrm{N}$ fertilization and their interaction effects on soil health. We hypo- 
thesize that soil biological, physical, and chemical properties can be affected by CRM left on the soil surface and its removal process by creating soil conditions that are not conducive for optimal plant growth and development.

\section{Materials and Methods}

\subsection{Experimental Design}

The study was established in Fall 2010 on a Canisteo silty clay loam (Fine-loamy, mixed, superactive, calcareous, mesic Typic Endoaquolls) and Harps loam (Loam, mixed, superactive, mesic Typic Calciaquolls) soil association at the Iowa State University Agronomy Research Farm located in Central, Iowa $\left(42.0^{\circ} \mathrm{N}\right.$; $\left.93.8^{\circ} \mathrm{W}\right)$. The average annual temperature and annual precipitation at the site for 2011 were $8.7^{\circ} \mathrm{C}$ and $807 \mathrm{~mm}$, respectively. In 2012, the average annual temperature was $11.4^{\circ} \mathrm{C}$ and annual precipitation was $512 \mathrm{~mm}$ (Figure 1). Prior to this field study, the site was in a corn-soybean [Glycine $\max$ (L.) Merr.] rotation under conventional tillage, which was chisel plowed in the fall and chisel plow plus disc in the spring. Source of $\mathrm{N}$ fertilizer used was liquid urea-ammonium nitrate $32 \% \mathrm{~N}$ (UAN), which was side-dressed injected below the soil surface in May after planting using agronomic rates of $170 \mathrm{~kg} \mathrm{~N} \mathrm{ha}^{-1}$. Phosphorus $\left(\mathrm{P}_{2} \mathrm{O}_{5}\right)$ and potassium $\left(\mathrm{K}_{2} \mathrm{O}\right)$ fertilizers were applied as needed to maintain optimum fertility levels so as not to restrict corn or soybean growth.

The field study consisted of two tillage systems; no-till (NT) and chisel plow (CP) with four CRM treatments 1) control; no CRM applied or removed, 2) removed; complete removal of $7.5 \mathrm{~cm}$ depth of CRM (fall 2010/2011-applied and removed in the spring of 2011/2012), 3) $2.5 \mathrm{~cm}$ depth of CRM (2010 fall-applied), and 4) $7.5 \mathrm{~cm}$ depth of CRM (2010 fall-applied). Three $\mathrm{N}$ rates $(0,180$, and 270 $\mathrm{kg} \mathrm{N} \mathrm{ha}{ }^{-1}$ ) were applied to tillage and CRM treatments in a randomized complete block design with split-split arrangements with three replications in a continuous corn system. The dimension of the main plot within each tillage system and replication was $24.2 \mathrm{~m}$ wide by $22.7 \mathrm{~m}$ long; while the sub-plots consisting of CRM treatments were $22.7 \mathrm{~m}$ long by $6.1 \mathrm{~m}$ wide. Furthermore, each CRM treatment sub-plot was split into $7.6 \mathrm{~m}$ long by $6.1 \mathrm{~m}$ wide to receive three $\mathrm{N}$ rates of 0,180 , and $270 \mathrm{~kg} \cdot \mathrm{N} \cdot \mathrm{ha}^{-1}$ randomly assigned. The field study was
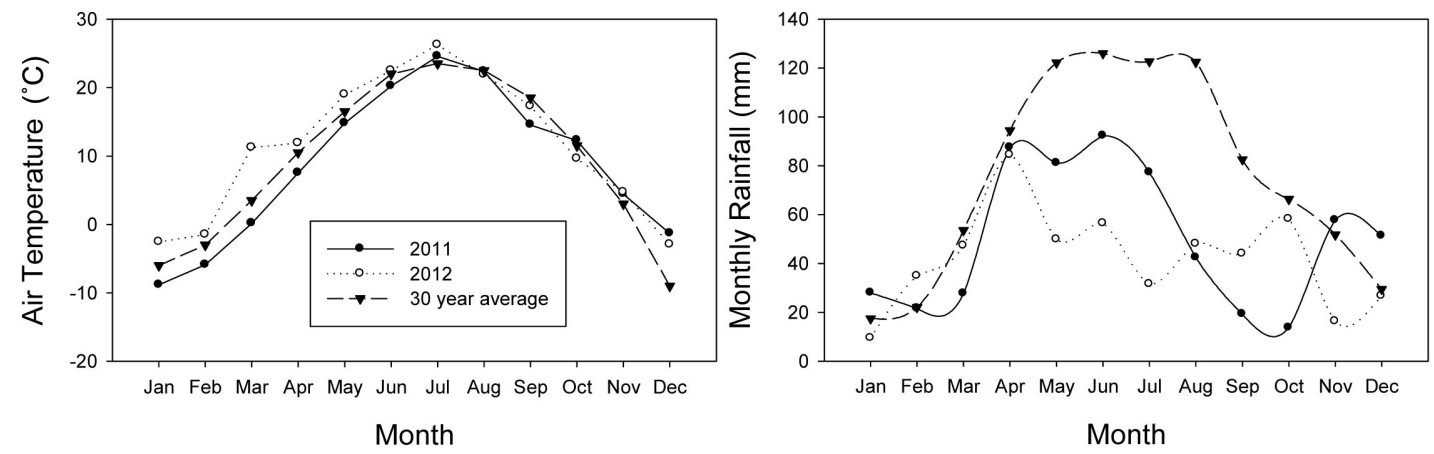

Figure 1. Average monthly air temperature and rainfall for 2011 and 2012 at the site, near Ames, Iowa. 
designed to monitor changes in selected soil health parameters with different levels of CRM depths on the soil surface.

Tillage treatments included NT where no disturbance except for the application and removal of CRM, seed planting, and $\mathrm{N}$ fertilizer application; while $\mathrm{CP}$ tillage was conducted in the spring by using a commercially available model with straight shanks and twisted sweeps. The shanks are mounted on four toolbars in a staggering order to ensure an effective spacing of $30 \mathrm{~cm}$ between shanks. The depth of tillage with CP was $22-25 \mathrm{~cm}$. Also, a field cultivator was used for secondary tillage after CP tillage, consisting of a horizontal implemented frame section with straight shanks and a smoothing arrow. The CRM treatments were randomly assigned to each tillage system and replication. The desired CRM depths were based on our first field evaluations at four different sites in Emmetsburg, Iowa, in 2009-2010 (data not published), where CRM was piled at the edge of the field in areas of $9.1 \mathrm{~m}$ wide by $30.5 \mathrm{~m}$ long. After CRM was removed, noticeable amounts of CRM, ranging from 2.5 to $7.5 \mathrm{~cm}$ deep were left on the soil surface. In the fall of 2010, CRM treatments were established for the 2011 growing season based on the above observations using CRM (70\% corncob and $30 \%$ corn stover) provided by POET Biorefinery from Emmetsburg, Iowa. The CRM quantity for each treatment depth was based on spreading CRM on an experimental plot, which was weighed on a field scale to determine equivalent amounts for each designed depth. The CRM equivalent to each treatment depth was then hauled and spread, using hand hoes, on each respective plot using a field cart. For the 2012 season, the same CRM treatments were kept on the same plots, except for removed CRM treatment, where fresh CRM was applied again in the fall of 2011 after corn harvest and removed early spring 2012. Furthermore, $\mathrm{N}$ rates of 0,180 , and $270 \mathrm{~kg} \cdot \mathrm{N} \mathrm{ha}^{-1}$ were randomly assigned to each CRM treatment. The $\mathrm{N}$ fertilizer source was $32 \% \mathrm{~N}$ liquid UAN $\left(\mathrm{NH}_{4} \mathrm{NO}_{3}\right)$, which was side-dressed and injected in May after planting corn, using a spoke point injector. The site was planted on $6^{\text {th }}$ May 2011 and $14^{\text {th }}$ May 2012 using a 111-day maturity corn variety (Pioneer, P33W84) with a seeding density of 79,000 seeds $\mathrm{ha}^{-1}$.

\subsection{Soil Sampling and Measurements}

Initial soil samples were collected in mid-October after harvest prior to the establishment of treatments in 2010. Those soil samples were analyzed to establish the baseline for the different parameters of the soil prior to the start of the study. In the fall of 2011 and 2012, soil samples were collected and analyzed for soil organic carbon (SOC), soil total nitrogen (STN), soil bulk density $\left(\rho_{\mathrm{b}}\right)$, and soil $\mathrm{pH}$. Soil sampling was done by collecting twelve $1.7 \mathrm{~cm}$ diameter soil cores from depths: 0 - 7.5, 7.5 - 15, and $15-30 \mathrm{~cm}$ for each treatment plot. Collected soil cores for each sample were mixed and sieved through a $2 \mathrm{~mm}$ sieve, then air dried before analysis. The SOC and STN analyses were done by dry combustion using a CN analyzer (TRUSPEC, LECO Corporation, St. Joseph, MI). Soil pH 
was measured by mixing 1:1 soil to water ratio using an AR15 pH meter (Accumet $^{\circledR}$ Research, Fisher Scientific International Inc.). Soil samples with $\mathrm{pH}$ values greater than 7.1, had a separate inorganic $\mathrm{C}$ analysis done to correct total soil $\mathrm{C}$ values, by subtracting them from the total soil $\mathrm{C}$ results to obtain SOC. The inorganic $\mathrm{C}$ determination was done by using a modified pressure calcimeter method [13].

Soil samples for $\rho_{\mathrm{b}}$ were simultaneously conducted during the soil sampling for total $\mathrm{C}$ and $\mathrm{N}$ for each depth by taking three $1.7 \mathrm{~cm}$ diameter soil cores from each treatment plot for $0-7.5,7.5-15$, and $15-30 \mathrm{~cm}$ soil depths. Soil cores were carefully removed from probes and placed in a paper bag. Once in the lab, soil samples were oven dried at $105^{\circ} \mathrm{C}$ for 24 hours and weighed. The dried soil mass was divided by the soil core volume to determine $\rho_{\mathrm{b}}$ in $\mathrm{Mg} \cdot \mathrm{m}^{-3}$. To convert SOC and STN concentrations ( $\mathrm{mg} \cdot \mathrm{g}^{-1}$ dry soil) to mass (C stocks) per area basis $\left(\mathrm{Mg} \mathrm{ha}^{-1}\right)$ the SOC and STN concentrations values were multiplied by the mean $\rho_{\mathrm{b}}$ value and soil depth.

\subsection{Soil Microbial Biomass Carbon}

Soil samples for the determination of microbial biomass carbon (MBC) were collected from the site at four different times during the growing season for both years. Collection occurred after planting in mid-May and subsequently in June, July, and September from all tillage, CRM, and N treatments. The MBC was determined by performing a fumigation-extraction [14], where six $1.7 \mathrm{~cm}$ diameter soil cores were collected from the top $15 \mathrm{~cm}$. The soil samples were immediately processed in the lab by sieving them through a $2 \mathrm{~mm}$ sieve at field moisture conditions. Five $g$ soil samples were taken for determining gravimetric soil moisture content to be used in the calculation of MBC on soil dry weight basis. At the same time, two soil samples of $20 \mathrm{~g}$ each were placed in $50 \mathrm{ml}$ glass beakers. One soil sample was used for the non-fumigated analysis, while the other sample was placed in a vacuum desiccator to be fumigated with ethanol-free chloroform $\left(\mathrm{CHCl}_{3}\right)$ for 24 hours. After the fumigation process was completed, all samples were extracted with $100 \mathrm{~mL}$ of $0.5 \mathrm{M}$ potassium sulfate $\left(\mathrm{K}_{2} \mathrm{SO}_{4}\right)$ and placed in a shaker for 30 minutes, and then filtered through a Whatman No. 42 filter paper. In order to determine the background level of $\mathrm{C}$ in the filter paper during extraction process, a blank sample made of $0.5 \mathrm{M} \mathrm{K}_{2} \mathrm{SO}_{4}$ was processed with the rest of the samples. The filtered solution was measured with an Elementarliqui-TOC carbon analyzer for C (Americas Inc., Mt. Laurel, New Jersey). The $\mathrm{MBC}$ for the soil was calculated on an oven-dry weight basis.

\subsection{Water Stable Aggregates}

Soil samples for water stable aggregates (WSA) were collected from all tillage, CRM, and N treatments in the fall of 2011 and fall of 2012. Soil samples collected in fall 2010 were analyzed to establish the baseline data of the soil physical properties prior to the start of the experiment. A single soil core was randomly taken 
using a $7.6 \mathrm{~cm}$ diameter golf course hole-cutter to a soil depth of $15 \mathrm{~cm}$; then the sample was brought back to the lab where it was sieved through an $8 \mathrm{~mm}$ sieve. Through this process, undesirable materials such as plant residue, rocks, corncob, and grains were removed. The soil samples were then air-dried and ready for analysis following the procedure by [15].

A $100 \mathrm{~g}$ of soil from each sample was placed at the top of a set of six sieves stacked top to bottom as follows: $4,2,1,0.50,0.25$, and $0.053 \mathrm{~mm}$. The set of six sieves were then submerged into a wet aggregate apparatus container filled with deionized water at $\sim 21^{\circ} \mathrm{C}$ and vertically oscillated for 5 minutes with a stroke length of $2 \mathrm{~cm}$. The frequency of oscillation was maintained at 90 strokes $\mathrm{min}^{-1}$. A wet aggregate apparatus is a custom-made machine in which the $20-\mathrm{cm}$ diameter sieves could be fitted [16]. It was noted that soil passed through the last sieve after 5 minutes of constant stroking. This was considered as aggregate size of $<0.053 \mathrm{~mm}$, which was captured by a plastic tub at the bottom of the aggregate apparatus. Then, each aggregate size was washed into plastic tubs using deionized water and oven dried at $65^{\circ} \mathrm{C}$ until all water in the tubs had evaporated. The weight of each aggregate size fraction was determined by weighing the plastic tub and dry aggregates and subtracting the plastic tub weight. The WSA for each fraction size is expressed as a percentage of the total sample weight on an oven-dry basis. Soil aggregate-associated total $\mathrm{C}$ was determined for each size fraction that was collected as described above, where oven-dried different aggregate size fractions were stored in a coin envelop for SOC analysis. The soil samples of each aggregate size fractions were ground with mortar and pestle and analyzed for SOC using a dry combustion method by using $\mathrm{CN}$ analyzer (TRUSPEC, LECO Corporation, St. Joseph, MI).

\subsection{Soil Penetration Resistance}

Soil penetration resistance (SPR) readings were collected following the application of CRM treatments. Measurements were taken two times during the study including spring 2011 and spring 2012. The SPR was determined using a Rimik CP-20 penetrometer (Soil Measurement System, Tucson, AZ) using a $30^{\circ}$ cone with a $1.27 \mathrm{~cm}$ diameter base targeting an insertion speed of $1.3 \mathrm{~m} \cdot \mathrm{min}^{-1}$, with a range of 0.01 to $2 \mathrm{~m} \cdot \mathrm{min}^{-1}$. The SPR measurements were conducted for tillage, CRM treatments, and $180 \mathrm{~kg} / \mathrm{ha} \mathrm{N}$ rate, where three random insertion points per plot were recorded at $2.5 \mathrm{~cm}$ soil depth increments down to $60 \mathrm{~cm}$.

\subsection{Statistical Analysis}

Data for soil health parameters were analyzed using the statistical analysis procedure of PROC MIXED [17] with repeated measurements. A compound symmetry-covariance structure was used for repeated measures. Tillage system was considered as the main plot treatment, which was split into different CRM levels as the split treatments, $\mathrm{N}$ rates as split-split-plot, and date of measurements as the repeated measure variable. Mean separation was determined using the PDIFF procedure and significant difference was determined at $\mathrm{p} \leq 0.05$. 


\section{Results and Discussion}

\subsection{Soil Organic Carbon and Total Nitrogen}

During this study, SOC rate of change was significant at different depths $(\mathrm{p}=$ 0.006) for both tillage systems. Changes in SOC were mostly negative across CRM treatments, tillage systems, and soil depths (Figure 2(a) and Figure 2(b)), with the exception at $15-30 \mathrm{~cm}$ soil depth under CP (control $=0.13 \mathrm{Mg} \cdot \mathrm{ha}^{-1} \cdot \mathrm{yr}^{-1}$, average CRM $\left.=0.25 \mathrm{Mg} \cdot \mathrm{ha}^{-1} \cdot \mathrm{yr}^{-1}\right)$. Also, SOC gain was observed in NT control $\left(0.20 \mathrm{Mg} \cdot \mathrm{ha}^{-1} \cdot \mathrm{yr}^{-1}\right)$ at $15-30 \mathrm{~cm}$ soil depth. Other positive rates of changes in SOC were observed at removed CRM at $7.5-15 \mathrm{~cm}$ soil depth $(0.24$ $\left.\mathrm{Mg} \cdot \mathrm{ha}^{-1} \cdot \mathrm{yr}^{-1}\right)$, at $15-30 \mathrm{~cm}$ soil depth $\left(0.39 \mathrm{Mg} \cdot \mathrm{ha}^{-1} \cdot \mathrm{yr}^{-1}\right)$, and $7.5 \mathrm{CRM}$ at 15 $30 \mathrm{~cm}$ soil depth $\left(0.22 \mathrm{Mg} \cdot \mathrm{ha}^{-1} \cdot \mathrm{yr}^{-1}\right)$. Even though, the rate of change of SOC is not significantly different a positive change in SOC at $15-30 \mathrm{~cm}$ soil depth shows that the change in field management by introducing CRM affected soil health.

Additionally, STN rate of change was affected by tillage systems ( $\mathrm{p} \leq 0.0001)$, where all CRM treatments showed a decline in STN rate under CP system for all soil depths (average $-0.14 \mathrm{Mg} \cdot \mathrm{ha}^{-1} \cdot \mathrm{yr}^{-1}$ ) apart from control treatment at $0-7.5$ $\mathrm{cm}$ soil depth $\left(0.13 \mathrm{Mg} \cdot \mathrm{ha}^{-1} \cdot \mathrm{yr}^{-1}\right)$. However, the rate of change in STN with NT for all CRM treatments and soil depths was positive (average $0.20 \mathrm{Mg} \cdot \mathrm{ha}^{-1} \cdot \mathrm{yr}^{-1}$ ). The rate of change of STN (gain or loss) associated with both tillage systems
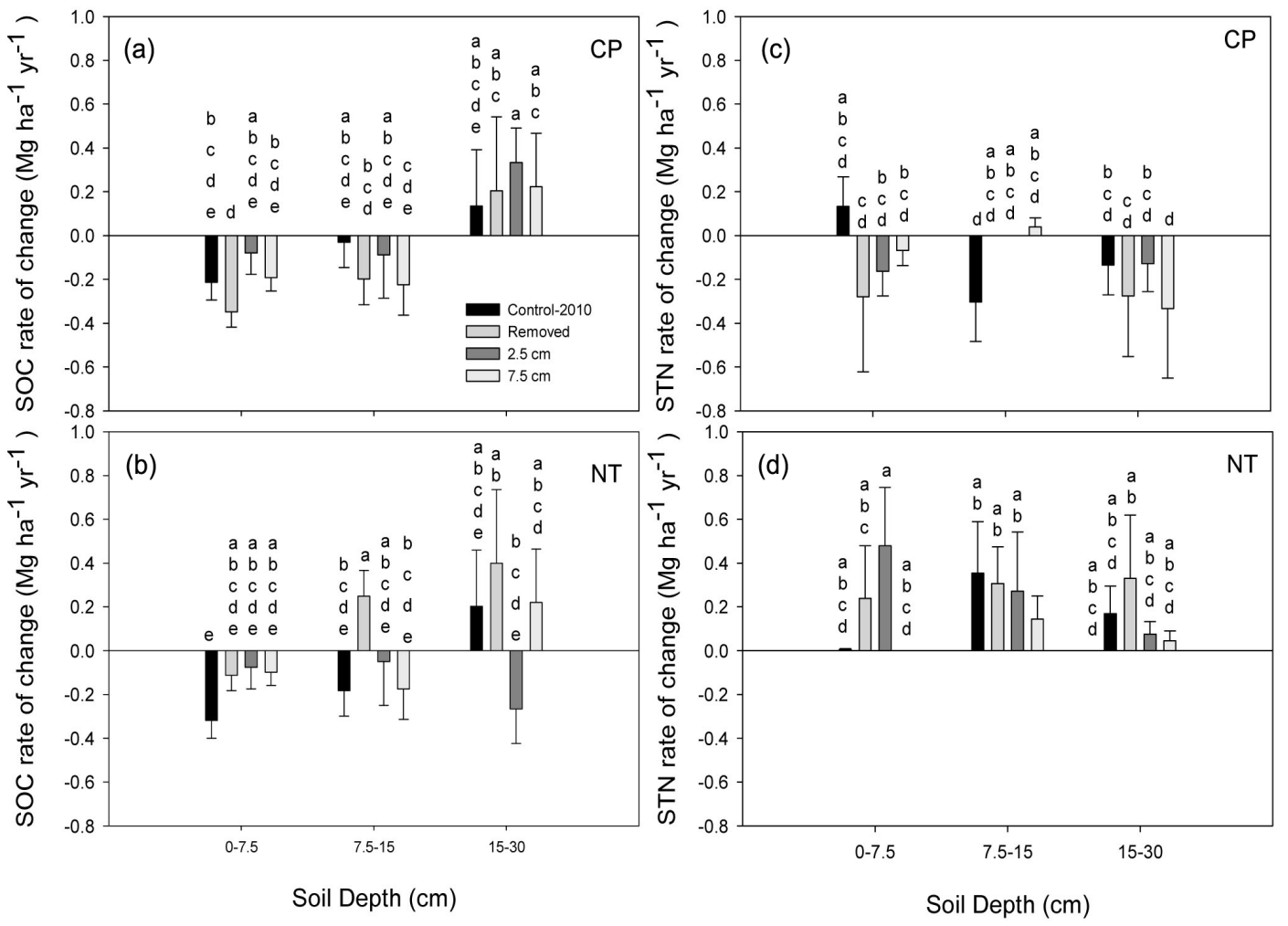

Figure 2. CRM effects on SOC ((a) and (b)) and STN ((c) and (d)) rate of change averaged across N rates from 2010 to 2012 under NT and CP tillage systems at the site near Ames, Iowa. Means of CRM treatments with the same letters within each soil depth and tillage system are not significantly different at $\mathrm{p} \leq 0.05$. 
within each depth was not significantly different for CRM treatments (Figure 2(c) and Figure 2(d)). The increase in STN rate in this study with NT is largely due to less soil disturbance and greater soil moisture retention. However, low SOC and STN in the 2012 season may be due to the drought conditions in 2012 (Figure 1). Yet, the increase in SOC at the $15-30 \mathrm{~cm}$ soil depth for both tillage systems can be a result of CRM incorporation at lower depths for CP and greater soil moisture content with NT increasing root development and soil organic matter contribution [18]. The lack of significant differences in SOC and STN changes between CRM treatments and $\mathrm{N}$ rates in this experiment is most likely due to the short duration of treatments effect [19]. Also the changes in SOC and STN observed during this experiment can be attributed to the large amount of CRM applied resulting in greater raw organic materials input coupled with management effects (i.e., $\mathrm{N}$ rate and tillage), and a possible increase/decrease of SOC and STN mineralization rate [18] [20].

\subsection{Soil Microbial Biomass Carbon}

Results of soil $\mathrm{MBC}$ is presented as an average across tillage systems and $\mathrm{N}$ rates due to no significant differences between tillage systems and $\mathrm{N}$ rates within each year ( $\mathrm{p}=0.1983$ and $\mathrm{p}=0.7177$ for 2011 and 2012 , respectively) in affecting soil $\mathrm{MBC}$ content (Figure 3). The reason for monitoring soil MBC over time in this study was to determine the CRM treatment effect as the most sensitive soil health indicator. Soil MBC throughout the growing season for $2.5 \mathrm{~cm}$ and $7.5 \mathrm{~cm}$ CRM treatments were generally greater than that for control-2010 and removed CRM treatments (average of control-2010 and removed-2011 treatments $=321$ $\mu \mathrm{g} \cdot \mathrm{C} \cdot \mathrm{g}^{-1}$ dry soil, average of 2.5 and $7.5 \mathrm{CRM} 2011$ treatments $=375 \mu \mathrm{g} \cdot \mathrm{C} \cdot \mathrm{g}^{-1}$ dry soil, average of control-2010 and removed 2012 treatments $=356 \mu \mathrm{g} \cdot \mathrm{C} \cdot \mathrm{g}^{-1} \mathrm{dry}$ soil, and average of 2.5 and 7.5 CRM 2012 treatments $=390 \mu \mathrm{g} \cdot \mathrm{C} \cdot \mathrm{g}^{-1} \mathrm{dry}$ soil). The soil MBC trend over time was significant in June and July for both years,
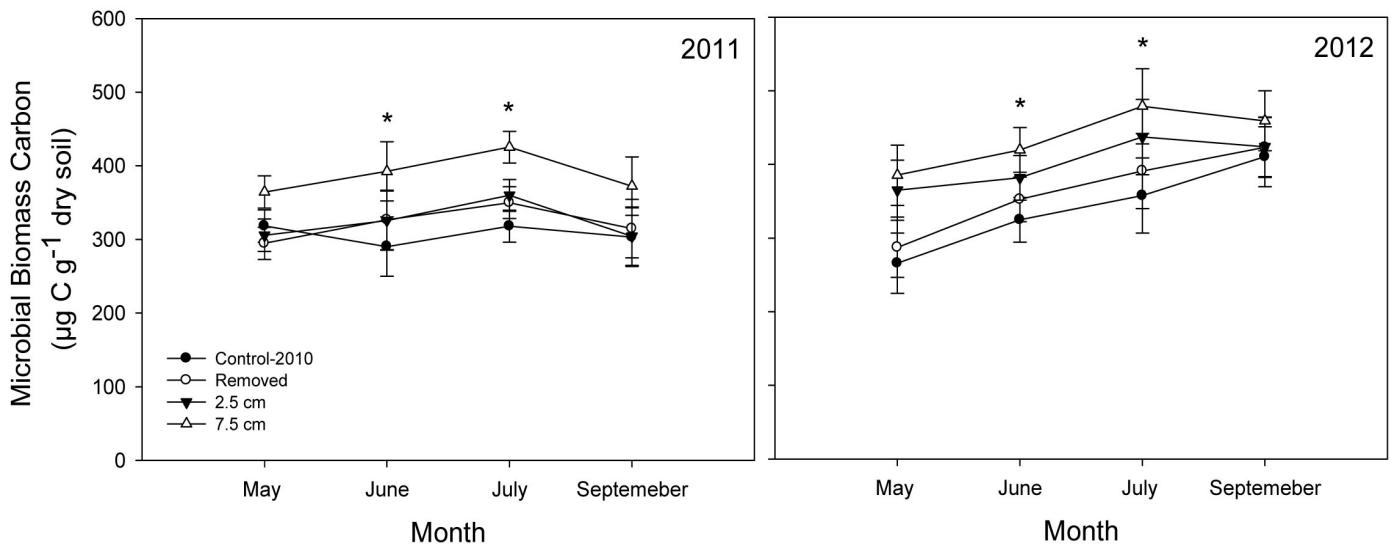

Figure 3. CRM effects on microbial biomass carbon at top $15 \mathrm{~cm}$ across tillage system and $\mathrm{N}$ rates during 2011 and 2012 at the site, near Ames, Iowa. Standard errors are for CRM treatments within each year and each month. A significant difference between CRM treatments within each month is noted with an asterisk $\left({ }^{*}\right)$ at $\mathrm{p} \leq 0.05$. 
where $\mathrm{MBC}$ for $2.5 \mathrm{~cm}$ and $7.5 \mathrm{~cm}$ CRM treatments were significantly greater than that for control-2010 or removed CRM treatments. High soil MBC observed during June and July is consistent with findings by other studies, where this increase was attributed to an increase in organic matter input [21], and the decomposition of these organic materials throughout the growing season. The $2.5 \mathrm{~cm}$ and $7.5 \mathrm{~cm}$ CRM treatments greatly influenced $\mathrm{MBC}$ in this experiment over tillage systems and $\mathrm{N}$ rates, which was documented by another study [22] [23].

\subsection{Water Stable Aggregates and Soil Aggregate-Associated Carbon}

The WSA was measured to determine the potential change in soil structure at the aggregate level as affected by CRM treatments, tillage systems, and $\mathrm{N}$ rates. There were interactions between years, CRM treatments, and aggregate size fractions ( $\mathrm{p}=0057)$. However, in this study, tillage systems and $\mathrm{N}$ rates showed no effects on aggregate stability during the 2 -yr study $(p=0.8698$ and $p=0.8447$ for 2011 and 2012, respectively). Therefore, an average of the same aggregate size fractions across tillage systems and $\mathrm{N}$ rates was used in Figure 4. The WSA was separated into seven aggregate size fractions $(<0.053,0.053-0.25,0.25-0.50$, $0.50-1,1-2,2-4$ and $>4 \mathrm{~mm}$ ). For the purpose of this discussion, aggregate size fractions of 0.50 to $>4 \mathrm{~mm}$ will be discussed as macro-aggregates, while $<0.053$ to $0.50 \mathrm{~mm}$ will be discussed as micro-aggregates. In both years, CRM treatments showed no significant effect on WSA percentages within each aggregate size fraction. The average of macro-aggregates across tillage systems, $\mathrm{N}$ rates, and CRM treatments accounted for 58\%, while micro-aggregates accounted for the rest of $42 \%$ in 2011. In 2012, macro-aggregates decreased by $8 \%$, while micro-aggregates increased by $2 \%$. Furthermore, aggregate fraction sizes of $2-4$ and $1-2 \mathrm{~mm}$ were the most affected within the macro-aggregates range

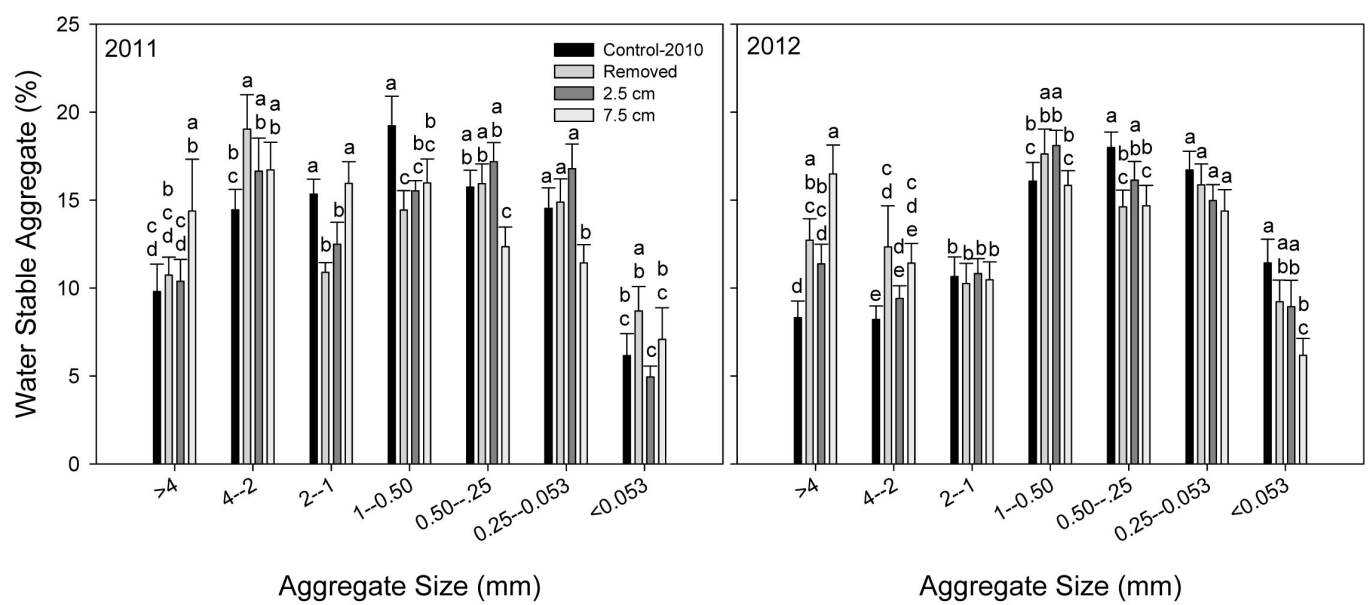

Figure 4. CRM effects on water aggregate stability size fractions percentage distribution averaged across two tillage systems and three $\mathrm{N}$ rates for 2011 and 2012 at the site, near Ames, Iowa. CRM treatments means within each size fraction with the same letters in each year are not significantly different at $\mathrm{p} \leq 0.05$. 
decreasing by $6.3 \%$ and $3.1 \%$ across all CRM treatments, respectively, from 2011 to 2012. The CRM treatments show no significant differences in WSA percentage at each aggregate size fraction. However, the overall decrease of WSA from 2011 to 2012 points out the potential of a negative effect of field management operations during the application and removal of CRM treatments due to machinery traffic for tillage, planting, and fertilizing operations [24] [25] [26].

The aggregate-associated C content was primarily affected by the relationship between aggregate fraction size and CRM treatments in 2011 and 2012. No differences were observed due to tillage systems and $\mathrm{N}$ rates $(\mathrm{p}=0.0932)$, thus an average across these treatments is presented in Figure 5. During this study, CRM treatments showed no effect on aggregate-associated C in both years. An average across all CRM treatments for macro-aggregates associated $\mathrm{C}$ content in 2011 was $5.91 \mathrm{~g} \cdot \mathrm{C} \cdot \mathrm{kg}^{-1}$, whereas micro-aggregates associated C content was 4.97 $\mathrm{g} \cdot \mathrm{C} \cdot \mathrm{kg}^{-1}$. Moreover, in 2012, there was a decrease in macro-aggregates associated $\mathrm{C}$ content by $0.77 \mathrm{~g} \cdot \mathrm{C} \cdot \mathrm{kg}^{-1}$, while micro-aggregates associated $\mathrm{C}$ content increase by $0.16 \mathrm{~g} \cdot \mathrm{C} \cdot \mathrm{kg}^{-1}$. The macro-aggregates fractions of $2-4 \mathrm{~mm}$ and $1-2 \mathrm{~mm}$ sizes across all CRM treatments showed a decline in aggregate-associated $\mathrm{C}$ content by $2.58 \mathrm{~g} \cdot \mathrm{C} \cdot \mathrm{kg}^{-1}$ and $1.31 \mathrm{~g} \cdot \mathrm{C} \cdot \mathrm{kg}^{-1}$, respectively, from 2011 to 2012 . Also, an increase in micro-aggregates $\mathrm{C}$ content was observed for the $0.25-0.50 \mathrm{~mm}$ and $0.053-0.25 \mathrm{~mm}$ size fractions of $0.10 \mathrm{~g} \cdot \mathrm{C} \cdot \mathrm{kg}^{-1}$ and $0.22 \mathrm{~g} \cdot \mathrm{C} \cdot \mathrm{kg}^{-1}$, respectively, from 2011 to 2012. The similarities between WSA percentage and its aggregate-associated $\mathrm{C}$ content can be explained by the aggregate hierarchy theory of soil aggregate fractions arrangement and accessibility of soil $\mathrm{C}$ to the microbial community, for loss or gain of soil organic matter [27]. In this arrangement, micro-aggregates were protected by macro-aggregates and a significant amount of fresh C (CRM), which further protect micro-aggregates from microbial activities. It is well documented that cultivation (i.e., tillage) reduces soil WSA percentage and its associated $\mathrm{C}$ content at the macro-aggregates level due to soil

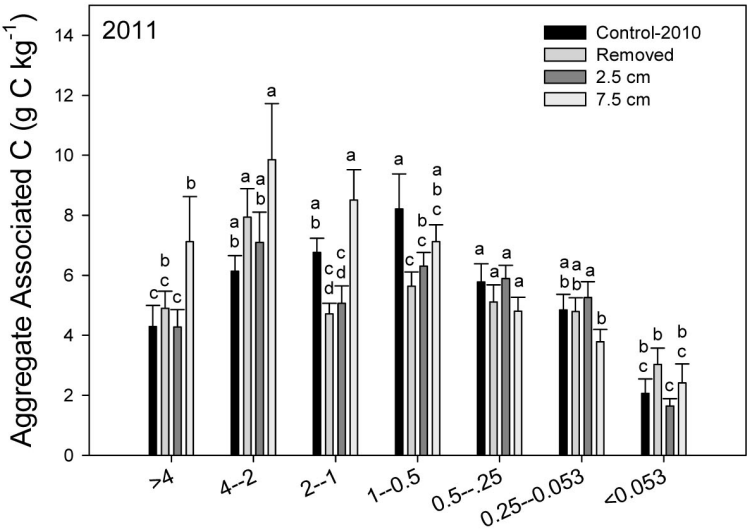

Aggregate Size $(\mathrm{mm})$

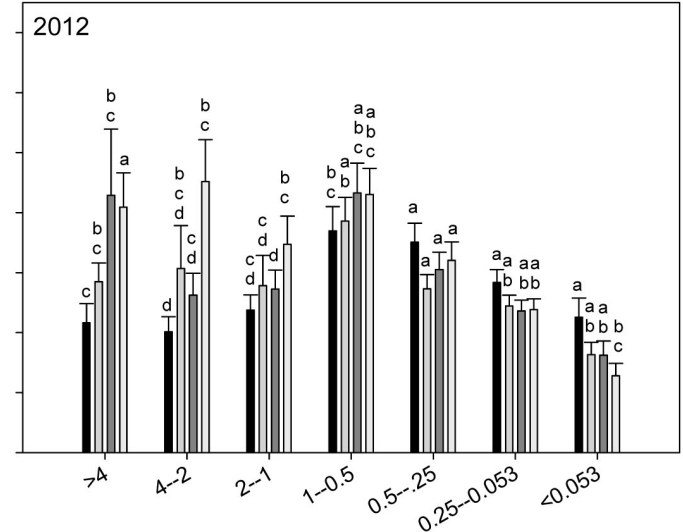

Aggregate Size $(\mathrm{mm})$

Figure 5. CRM effects on aggregate size fractions associated carbon content averaged across two tillage systems and three $\mathrm{N}$ rates in 2011 and 2012 at the site, near Ames, Iowa. CRM treatments means within each size fraction with the same letters in each year are not significantly different at $\mathrm{p} \leq 0.05$. 
disturbance and change in its aggregate distribution [28]. However, in our study, no significant differences were found between tillage systems. This can be attributed to the length of treatment effects (2-yr) since the implementation of tillage systems and the application of CRM treatments offsetting any significant changes in the short term.

\subsection{Soil Penetration Resistance and Bulk Density}

The SPR measures treatments' effects on soil physical properties, the measurements were taken in the spring of 2011 and 2012 after tillage operations in order to determine tillage and CRM treatment effect on soil compaction; which are presented in Figure 6. In general, SPR values under CP and NT in both years show that Control-2010 and removed CRM treatments had greater SPR values compared to $2.5 \mathrm{~cm}$ and $7.5 \mathrm{~cm}$ CRM treatments at the top $15 \mathrm{~cm}$ soil depth in 2011 and 2012 (control-2010/removed-2011 $=1.44 \mathrm{MPa}$, CRM $2011=1.20 \mathrm{MPa}$, control-2010/removed-2012 $=0.93 \mathrm{MPa}$, and CRM $2012=0.87 \mathrm{MPa}$ ). On average, SPR for control CRM and removed CRM treatments across tillage systems and soil depths were greater than that for $2.5 \mathrm{~cm}$ and $7.5 \mathrm{~cm}$ CRM treatments for 2011 and 2012 by $0.25 \mathrm{MPa}$ and $0.02 \mathrm{MPa}$, respectively. Differences in SPR values between CRM treatments were not significant at lower soil depths for both tillage systems in both years. The increase in SPR values at the $15 \mathrm{~cm}$ soil depth for control-2010 and removed CRM treatments can be attributed to field operations, traffic, and removal of crop residue, while $2.5 \mathrm{~cm}$ and $7.5 \mathrm{~cm}$ CRM treatments had less exposure to traffic (CRM covering soil surface), except during application of CRM treatments during 2011. The low SPR values observed in

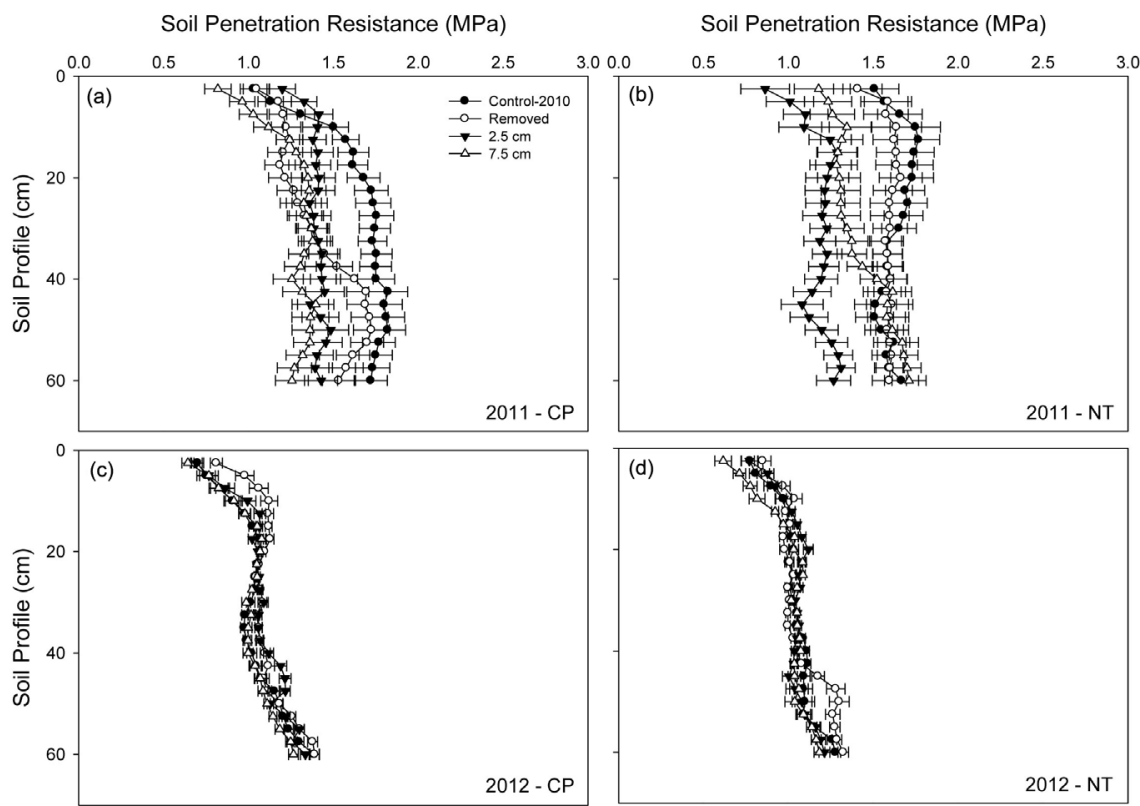

Figure 6. CRM effect on soil penetration resistance through soil profile within each tillage system for 2011 ((a) \& (b)) and 2012 ((c) \& (d)) at the site, near Ames, Iowa. Standard errors are for each CRM treatment within each tillage and soil depth. 
2012 across all CRM treatments and tillage systems could be attributed to the dry soil condition and the presence of CRM on the soil surface to minimize soil compaction [29]. Likewise, we observed that CRM treatments had no effect on soil bulk density $\left(\rho_{\mathrm{b}}\right)$ in 2011 (Table 1$)$ due to the short period of the experiment. However, we observed the following year (2012) that $2.5 \mathrm{~cm}$ and $7.5 \mathrm{~cm}$ CRM treatments showed slightly lower values of bulk density than the control and CRM treatments. The improvement in SPR and $\rho_{\mathrm{b}}$ in plots covered with CRM treatments was most likely due to residue cover mitigating soil surface compaction from equipment traffic that can cause high $\rho_{\mathrm{b}}[30]$.

\subsection{Treatments Effects on Soil pH}

Soil $\mathrm{pH}$ directly affects nutrient availability for plant growth and development and positions it as an important soil health indicator. Soil $\mathrm{pH}$ means, standard errors, and p-values are presented in Table 2. Changes in soil $\mathrm{pH}$ are often slow and small over time, as the results in this study, show no significant differences over two years, tillage, and CRM treatments. In general, significant differences were observed at different soil depths, and $\mathrm{N}$ rates, where soil $\mathrm{pH}$ across all

Table 1. CRM treatments effects on soil bulk density at the site near Ames, Iowa. A significant difference due to treatment is noted with an asterisk $\left(^{\star}\right)$ at $\mathrm{p} \leq 0.05$.

\begin{tabular}{cccc}
\hline Treatments & Mean & Std. Error & $\operatorname{Pr}(>|\mathrm{t}|)$ \\
\hline Year & 1.21 & 0.01309 & 0.255 \\
Tillage & 1.20 & 0.013083 & 0.177 \\
N rates & 1.23 & $6.538 \mathrm{e}-05$ & 0.0506 \\
Soil depth & 1.15 & 0.007685 & $8.72 \mathrm{e}-10^{*}$ \\
CRM Control & 1.24 & 0.018023 & 0.288175 \\
CRM Removed & 1.22 & 0.018023 & 0.596970 \\
CRM 2.5 cm & 1.22 & 0.018023 & 0.442572 \\
CRM 7.5 cm & 1.15 & 0.018023 & $0.000321^{\star}$ \\
\hline
\end{tabular}

Table 2. CRM treatments effects on soil $\mathrm{pH}$ at the site near Ames, Iowa. A significant difference due to treatment is noted with an asterisk $\left({ }^{*}\right)$ at $\mathrm{p} \leq 0.05$.

\begin{tabular}{cccc}
\hline Treatments & Mean & Std. Error & $\operatorname{Pr}(>|\mathrm{t}|)$ \\
\hline Year & 7.41 & $3.598 \mathrm{e}-02$ & 0.9979 \\
Tillage & 7.40 & $3.598 \mathrm{e}-02$ & 0.9184 \\
N rates & 7.42 & $1.803 \mathrm{e}-04$ & $0.0392^{\star}$ \\
Soil depth & 7.52 & $2.203 \mathrm{e}-02$ & $1.89 \mathrm{e}-06^{*}$ \\
CRM Control & 7.40 & $5.088 \mathrm{e}-02$ & 0.7066 \\
CRM Removed & 7.33 & $5.088 \mathrm{e}-02$ & 0.0956 \\
CRM 2.5 cm & 7.43 & $5.088 \mathrm{e}-02$ & 0.2002 \\
CRM 7.5 cm & 7.48 & $5.088 \mathrm{e}-02$ & 0.2002 \\
\hline
\end{tabular}


treatments for each soil depth $(0-7.5,7.5-15$, and $15-30 \mathrm{~cm})$ was $7.29,7.33$, and 7.50, respectively, having the biggest difference, especially at the lowest depth. Also, $\mathrm{N}$ rates across all CRM treatments show significant differences in soil $\mathrm{pH}$, where 0,180 , and $270 \mathrm{~kg} \cdot \mathrm{N} \cdot \mathrm{ha}^{-1}$ yielded $7.40,7.43$, and 7.28 , respectively. Moreover, soil $\mathrm{pH}$ values varied between 4.69 and 8.03 , showing a large variability in soil $\mathrm{pH}$, which can be attributed to the spatial variability within the plots, soil types, and CRM treatments [31].

\section{Conclusions}

The application of different CRM treatments with two tillage systems (CP and $\mathrm{NT})$, and three $\mathrm{N}$ rates $\left(0,180\right.$, and $\left.270 \mathrm{~kg} \cdot \mathrm{N} \cdot \mathrm{ha}^{-1}\right)$ show no significant differences in SOC and STN rate of change for all CRM treatments, tillage systems, and soil depths. Soil $\mathrm{C}$ change is affected by the length of the treatments, and the study duration of 2-yr is not sufficient to produce a significant change or significant trend. However, initial trends in STN under CP showed a decline to no changes across all treatments, while NT showed slightly positive changes in certain depths with no consistent trend reflecting the high variability and short-term treatments' effect. Meanwhile, changes in $\mathrm{MBC}$ values at different times in the growing season with $2.5 \mathrm{~cm}$ and $7.5 \mathrm{~cm}$ CRM treatments were affected differently as the depth of CRM increased, especially in June and July (mid-summer). The combined effects of CRM and tillage treatments were evident in affecting soil physical properties, such as soil macro-aggregates and micro-aggregates fractions and their associated $\mathrm{C}$ content by increasing soil micro-aggregates stability and associated $\mathrm{C}$ content. Improvement in $\rho_{\mathrm{b}}$, SPR, and aggregate stability was associated with high amounts of CRM left on the soil surface. The findings of this study show that the process of CRM removal can affect certain soil health parameters in the short term differently, where some soil health indicators such as MBC, WSA, and SPR are most sensitive to management effects in the short term. However, long-term evaluation of CRM field management is essential to the development of best management practices that minimize the impact on soil health.

\section{Conflicts of Interest}

The authors have no conflicts of interest regarding the publication of this article.

\section{References}

[1] Hood, E.E. (2016) Plant-Based Biofuels. F1000Research, 5, Article No. 185. https://doi.org/10.12688/f1000research.7418.1

[2] Kim, T.H. and Tae, H.K. (2014) Overview of Technical Barriers and Implementation of Cellulosic Ethanol in the U.S.. Energy, 66, 13-19. https://doi.org/10.1016/j.energy.2013.08.008

[3] Morales, M., Quintero, J., Conejeros, G. and Aroca, G. (2015) Life Cycle Assesment of Lignocelluslosic Bioethanol: Environmental Impacts and Energy Balance. Renewable and Sustainable Energy Reviews, 42, 1349-1361. 
https://doi.org/10.1016/j.rser.2014.10.097

[4] Villamil, M.B., Joseph, L. and Emerson, D.N. (2015) Corn Residue, Tillage, and Nitrogen Rate Effects on Soil Properties. Soil and Tillage Research, 151, 61-66. https://doi.org/10.1016/j.still.2015.03.005

[5] Licht, M.A. and Al-Kaisi, M. (2005) Strip-Tillage Effect on Seedbed Soil Temperature and Other Soil Physical Properties. Soil and Tillage Research, 80, 233-249. https://doi.org/10.1016/j.still.2004.03.017

[6] Singh, N.B., Amit, S. and Deepmala, S. (2010) Autotoxicity of Maize and Its Mitigation by Plant Growth Promoting Rhizobacterium Paenibacillus Polymyxa. Allelopathy Journal, 1, 195-204.

[7] Al-Kaisi, M. and Kwaw-Mensah, D. (2007) Effect of Tillage and Nitrogen Rate on Corn Yield and Nitrogen and Phosphorus Uptake in a Corn-Soybean Rotation. Agronomy Journal, 99, 1548-1558. https://doi.org/10.2134/agronj2007.0012

[8] Loecke, T.D., Cambardella, C.A. and Liebman, M. (2012) Synchrony of Net Nitrogen Mineralization and Maize Nitrogen Uptake Following Applications of Composted and Fresh Swine Manure in the Midwest U.S.. Nutrient Cycling in Agroecosystems, 93, 65-74. https://doi.org/10.1007/s10705-012-9500-6

[9] Al-Kaisi, M. and Licht, M.A. (2004) Effect of Strip Tillage on Corn Nitrogen Uptake and Residual Soil Nitrate Accumulation Compared with No-Tillage and Chisel Plow. Agronomy Journal, 96, 1164-1171. https://doi.org/10.2134/agronj2004.1164

[10] Clive, A.K., Alan, E.R., Len, J.W., Graeme, D.B., Chris B. and John A.K. (2013) Carbon-Nutrient Stoichiometry to Increase Soil Carbon Sequestration, Soil Biology and Biochemistry, 60, 77-86. https://doi.org/10.1016/j.soilbio.2013.01.011

[11] Van Vleck, H.E. and King, J.Y. (2011) Root-Derived Contributions to Soil Respiration as Influenced by Agricultural Management Systems. Soil Science Society of America Journal, 75, 1839-1850. https://doi.org/10.2136/sssaj2010.0428

[12] Mu, Z., Kimura, S.D., Toma, Y. and Hatano, R. (2008) Evaluation of the Soil Carbon Budget Under Different Upland Cropping Systems in Central Hokkaido, Japan. Soil Science and Plant Nutrition, 54, 650-661. https://doi.org/10.1111/j.1747-0765.2008.00279.x

[13] Sherrod, L.A., Dunn, G., Peterson, G.A. and Kolberg, R.L. (2002) Inorganic Carbon Analysis by Modified Pressure-Calcimeter Method. Soil Science Society of America Journal, 66, 299-305. https://doi.org/10.2136/sssaj2002.2990

[14] Horwath, W.R. and Paul, E.A. (1994) Microbial Biomass. In: Weaver, R.W., Angle, S., Bottomley, P., Bezdicek, D., Smith, S., Tabatabai, A. and Wollum, A., Eds., $M e-$ thods of Soil Analysis. Part 2 Microbiological and Biochemical Properties, Soil Science Society of America, Madison, WI, USA, 753-773.

https://doi.org/10.2136/sssabookser5.2.c36

[15] Kemper, W.D. and Rosenau, R.C. (1986) Aggregate Stability and Size Distribution. In: Klute, A., Ed., Methods of Soil Analysis. Part 1 Physical and Mineralogical Methods, 5.1, Second Edition, Soil Science Society of America, Madison, WI, USA, 425-442. https://doi.org/10.2136/sssabookser5.1.2ed.c17

[16] Guzman, J.G. and Al-Kaisi, M. (2011) Landscape Position Effect on Selected Soil Physical Properties of Reconstructed Prairies in South Central Iowa. Journal of Soil and Water Conservation, 66, 183-191. https://doi.org/10.2489/jswc.66.3.183

[17] SAS Institute (2016) The SAS System for Windows (Release 9.4). SAS Institute, Cary, NC.

[18] Follett, R. (2001) Soil Management Concepts and Carbon Sequestration in Cropland Soils. Soil and Tillage Research, 61, 77-92.

https://doi.org/10.1016/S0167-1987(01)00180-5 
[19] Ellert, B.H., Janzen, H.H., McConkey, B.G. and Lal, R. (2001) Measuring and Comparing Soil Carbon Storage. In: Lal, R., Kimble, J.M., Follett, R.F. and Stewart, B.A., Eds., Assessment Methods for Soil Carbon, Lewis Publishers, Boca Rotan, FL, 131-146.

[20] Poffenbarger, H.J., Barker, D.W., Helmers, M.J., Miguez, F.E., Olk, D.C., Sawyer, J.E., Six, J. and Castellano, M.J. (2017) Maximum Soil Organic Carbon Storage in Midwest U.S. Cropping Systems When Crops Are Optimally Nitrogen-Fertilized. PLOS ONE, 12, e0172293. https://doi.org/10.1371/journal.pone.0172293

[21] Shi, Y., Lalande, R. and Hamel, C. (2013) Seasonal Variation of Microbial Biomass, Activity, and Community Structure in Soil under Different Tillage and Phosphorus Management Practices. Biology and Fertility of Soils, 49, 803-818.

https://doi.org/10.1007/s00374-013-0773-y

[22] Spedding, T.A. Hamel. C., Mehuys, G.R., and Madramootoo, C.A. (2004) Soil Microbial Dynamics in Maize-Growing Soil under Different Tillage and Residue Management Systems. Soil Biology and Biochemistry, 36, 499-512.

https://doi.org/10.1016/j.soilbio.2003.10.026

[23] Acosta-Martinez, V., Mikha, M.M., Sistani, K.R., Stahlman, P.W., Benjamin, J.G., Vigil, M.F. and Erickson, R. (2011) Multi-Location Study of Soil Enzyme Activities as Affected by Types and Rates of Manure Application and Tillage Practices. Agriculture, 1, 4-21. https://doi.org/10.3390/agriculture1010004

[24] Sarker, J.R., Singh, B.P., Cowie, A.L., Fang, Y., Collins, D., Badgery, W. and Dalal, R.C. (2018) Agricultural Management Practices Impacted Carbon and Nutrient Concentrations in Soil Aggregates, with Minimal Influence on Aggregate Stability and Total Carbon and Nutrient Stocks in Contrasting Soils. Soil and Tillage Research, 178, 209-223. https://doi.org/10.1016/j.still.2017.12.019

[25] Lehrsch, G.A., Sojka, R.E., Carter, D.L. and Jolley, P.M. (1991) Freezing Effects on Aggregate Stability Affected by Texture, Mineralogy, and Organic Matter. Soil Science Society of America Journal, 55, 1401-1406. https://doi.org/10.2136/sssaj1991.03615995005500050033x

[26] Le Bissonnais, Y. (2016) Aggregate Stability and Assessment of Soil Crustability and Erodibility: I. Theory and Methodology. European Journal of Soil Science, 67, 11-21. https://doi.org/10.1111/ejss.4_12311

[27] O'Brien, S.L. and Jastrow, J.D. (2013) Physical and Chemical Protection in Hierarchical Soil Aggregates Regulates Soil Carbon and Nitrogen Recovery in Restored Perennial Grasslands. Soil Biology and Biochemistry, 61, 1-13. https://doi.org/10.1016/j.soilbio.2013.01.031

[28] Six, J. and Paustian, K. (2014) Aggregate-Associated Soil Organic Matter as an Ecosystem Property and a Measurement Tool. Soil Biology and Biochemistry, 68, A4-A9. https://doi.org/10.1016/j.soilbio.2013.06.014

[29] Hamza, M. A., Al-Adawi, S. S. and Al-Hinai, K. A. (2011) Effect of Combined Soil Water and External Load on Soil Compaction. Soil Research, 49, 135-142. https://doi.org/10.1071/SR09144

[30] Blanco-Canqui, H. and Lal, R. (2007) Soil and Crop Response to Harvesting Corn Residues for Biofuel Production. Geoderma, 141, 355-362.

https://doi.org/10.1016/j.geoderma.2007.06.012

[31] Hangsheng, L., Wheeler, D., Bell, J. and Wilding, L. (2005) Assessment of Soil Spatial Variability at Multiple Scales. Ecological Modelling, 182, 271-290.

https://doi.org/10.1016/j.ecolmodel.2004.04.006 